This report was prepared as an account of work sponsored by the United States Government. Neither the United States nor the United States Atomic Energy Commission, nor any of their employees, nor any of their contractors, subcontractors, or their employees, makes any warranty, express or implied, or assumes any legal liability or responsibility for the accuracy, completeness or usefulness of any information, apparatus, product or process disclosed, or represents that its use would not infringe privately owned rights.

In the interest of prompt distribution, this LAMS report was not edited by the Technical Information staff.

Printed in the United States of America. Available from National Technical Information Service

U. S. Department of Commerce 5285 Port Royal Road Springfield, Virginia 22151

Price: Printed Copy $\$ 2$; Microfiche $\$ 0.95$

$$
4.00
$$


LA-4037-SOP, Rev., Suppl. 1 Standard Operating Procedures UC-41 \& 46

ISSUED: May 1973

\title{
Pajarito Plan for Radiation Emergency
}

\author{
by
}

H. C. Paxton

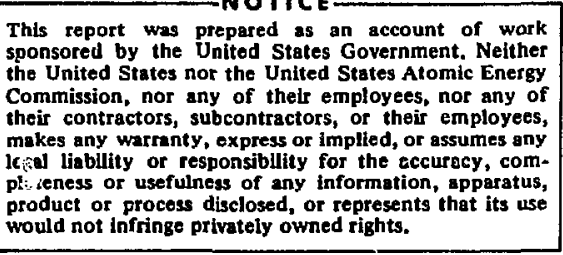

as account of work sponsored by the Unitod States Government. Neither the United States nor the United States Alomic Energy Commission, nor any of their employees, nor any of makes any warranty, express or implied, or assumes any 16 al liablity or responsibility for the eccuracy, compl:- teness or usefulness of any information, apparatus, would not infringe privately owned rights. 


\section{CONTENTS}

I. EXCURSION IN KIVA WITH PERSONNEL PRESENT

A. Action to be Observed

II. ACCIDENTAL EXCURSION DURING REMOTE OPERATION

A. Action to be Obsserved

III. EMERGENCY REQUIRING SITE EVACUATION

Approved:

It H Helmicle

For F-5 Nuciear Safety Committee

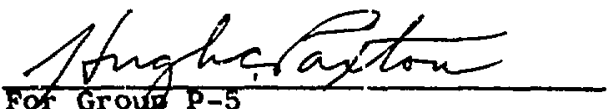

Fot Group p-5

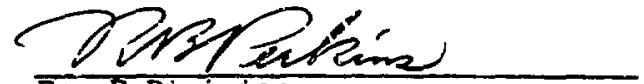

For P-Division

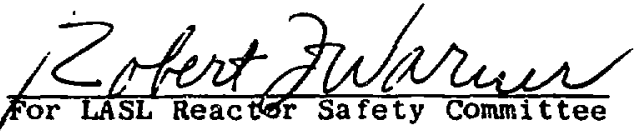

This is a Revision of the Emergency Plan of 4-6-71. 


\section{PAJARITO PLAN FOR RADIATION EMERGENCY}

I. EXCURSION IN KIVA WITH PERSONNEL PRESENT

An excursion during handling of fissile material at a Kiva would create an emergency requiring prompt action. Such an event would be indicated as follows.

1) Abnormal response of audible counters, shock effects including falling parts of an assembly, or blue glow would be apparent to those involved.

2) The radiation alarm in the $H-1$ office, $\mathrm{Am} 120 \mathrm{Bldg} 30$, would alert personisel outside the Kiva area.

A. Action to be Obsarved

1) The Kiva area as promptly as consistent with necessary rescue operations. Note that a high-level portable radiation detector is located near the main Kiva entrance.

2) Persons involved will report to a Health Physics Surveyor (Rm 120 Bldg 30), who will account for eviryone known by hilin or the crew Chigf to have been in the Kiva area. (Entry to the Kiva area is controlled by the Crew Chief during scheduled periods and by the Health Physics Surveyor at other times when fissils material may be handled.)

\footnotetext{
*xcept when in Kivas, fissile material of signiflcant quantity is either in containers designed for safe handling or subject to procedures for maintaining safe configurations.
}

3) The Senior Health Physics Surveyor at the site (or the $\mathrm{H}-1$ Group Leader) will advise the P-5 Group Leader about further action. Such action will be based upon the $\mathrm{H}-\mathrm{l}$ document "STANDARD OPERATING PROCEDURES, General and Emergency, Pajarito Site, TA-18", in particular, Part VII, "EMEIRGENCY MONITORING PROCEDURES".

4) The P-Division Leader and the LASL Director will be notified promptly.

II. ACCIDENTAL EXCUASION DURING REMOTE OPERATION.

An accidental excursion during remote operntion of a critical assembly is unlikely to create an emergency requiring prompt action. Such an excursion wolld be indicated by abnormal response of instrumentation in the control room, and by the radiation alarm in the $H-l$ office, $\mathrm{Am} 120 \mathrm{Bldg}$ 30. The monitoring television would give an idea of the extent of damage, if any. A. Action to be Observed

1) The gate to the Kiva arca will remain locked urtil the p-5 Group Leader permits reentry.

2) The Senior Health Physics Surveyor at the site will advise thi P-5 Group Leader about further action in acrordance with his "STANDARD UPERATING PROCEDURES, General and Emergency, Pajarito Site, TA-1k". In particular, his advice will bo sought before reentry into the Kiva area. 
3) The P-Division Leader and the

LASL Director will be notified promptly.

III. EMERGENCY REQUIRING STTE EVACUATION.

The remote location of each kiva is

such that an excursion at least an order of

magnitude greater than the largest that has

occurred accidentally would not create a

radiation emergency outside the Kiva area.

A disaster of external origin, which might

require site evacuation, would call into

effect the "GENERAL RADIOLOGICAL EMERGENCY

PLAN for Los Alamos Scientific Laboratory".

This plan is coordinated by the Health

Physics Group office with the help of

Health Physics Surveyors at the site. Re-

quired communication between the $\mathrm{H}-\mathrm{l}$ office,

Rn 120 Bldg 30, and other buildings at the

site would be with the assistance of the

Group P-5 secretary, Rm 109 Bldg 30. A

listing of local telephone numbers and

intercom stations to be called in case of

such an emergency is posted in toth of ices. 